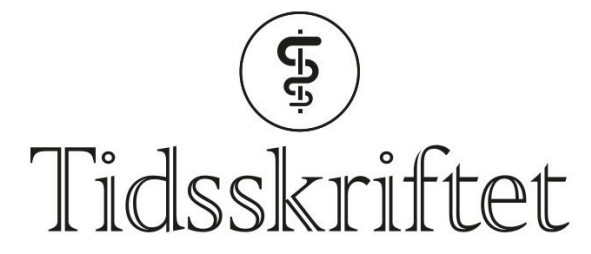

DEN NORSKE LEGEFORENING

\title{
Når uhellet er utenlands
}

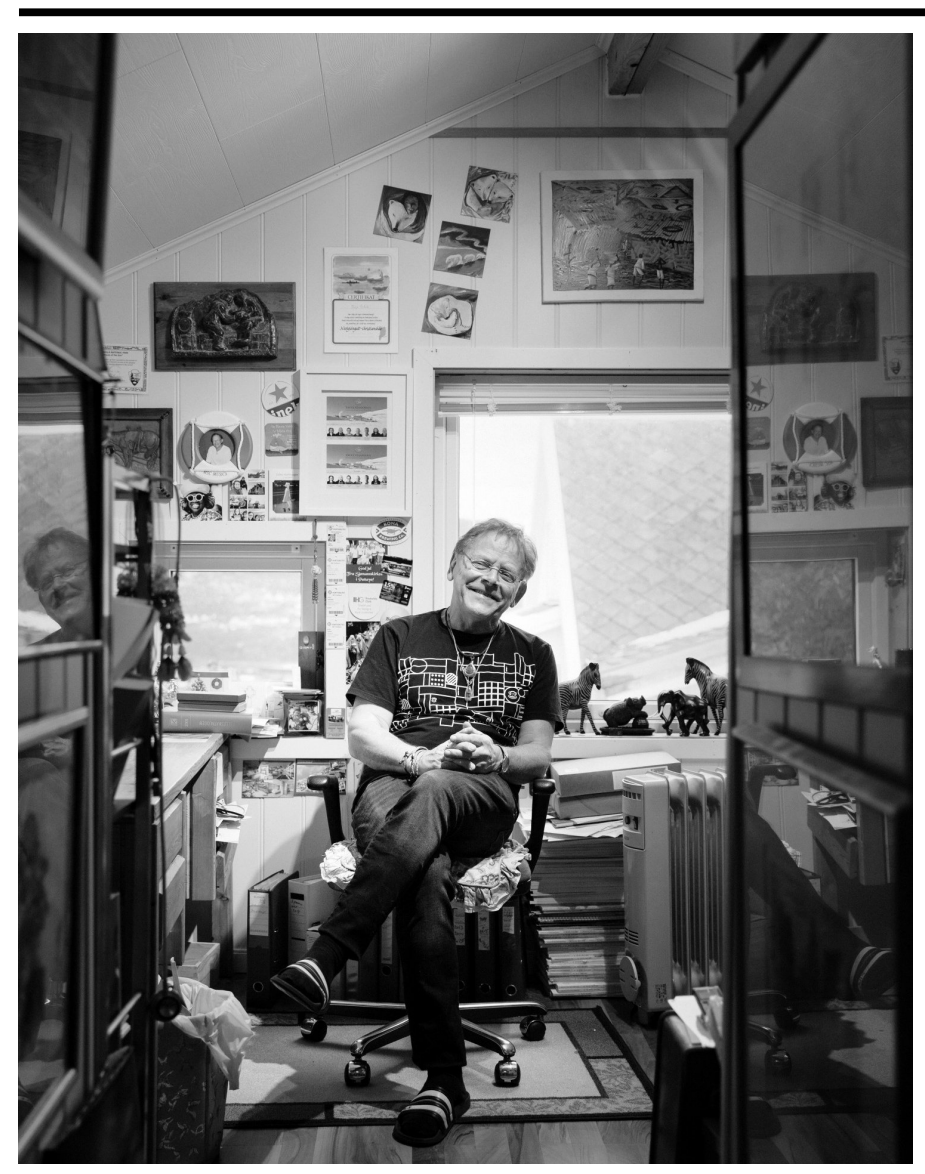

INTERVJU

\section{CHRISTINA SVANSTR $\varnothing M$}

E-post: christina@svanstrom.no

Går kroppen eller psyken på en smell i utlandet, hjelper det ikke å sette +47 foran 113. Terje Erlid lever av å bistå dem som ikke er på godfot med vilkårene i reiseforsikringen.

Vi er hjemme hos Terje Erlid. Huset ligger bare noen svinger unna hans barndomshjem. Fra en radio kommer myke samtidshits. Spiret på Harstad kirke ruver i stuens største vindu, med Vågsfjorden og fjerne fjell som bakteppe.

En liten hund ved navn Miko står ivrig logrende i midtgangen og holder øye med besøket. Stuebordet er fylt av bøker og papirer, veggflatene med fotografier og malerier. Erlid har gjort rom til tre skåler kjeks og sjokolade og byr oss en kopp kaffe attåt det han omtaler som «de sju slaga». 


\section{De sykes reiseselskap}

Allmennlege, sjømannslege, militærlege, vikarlege og ekspedisjonslege - nysgjerrig mann har mange navn. Det er da også Erlids hang til eventyr og nye erfaringer som har ført oss inn hit i dag. Reise uten forsikring - tør du? ble gitt ut i 2016. Den oppsummerer noen av fortellingene han har fått nær på livet gjennom de siste årene i selskapet Medicteam.

\section{Terje Erlid}

Født i 1948

Psykologi grunnfag Universitetet i Oslo 1973

Cand.med. Universitetet i Oslo 1977

Turnustjeneste Harstad sykehus 1977-78

Allmennlege i Harstad 1979-2005

Kursholder DHLR, vaksinasjon og sjømannssertifikat for bl.a. Hurtigruten og Seaworks

Harstad fra 2012

Medical escorts to Norway by air, Medicteam, fra 2012

- For å gjøre det kort og greit: Dere er et privat selskap, og dere tar betalt for å hente hjem dem som er blitt syke eller skadet i utlandet og ikke har reiseforsikring?

- Ja. Det finnes simpelthen ikke noe særlig alternativ for nordmenn som blir syke i utlandet og ikke har gyldig forsikring, sier Erlid.

Det begynte med en fortelling i VG for noen år siden. En familie delte der sin historie om sønnen som lå i koma i Thailand etter en bilulykke. Han hadde det som heter «helårsforsikring». Men han visste ikke at den var gyldig i kun 45 dager fra utreisetidspunktet. Døgnprisen på sykehuset var skyhøy, og familien kunne ikke få ham hjem.

- Jeg leste artikkelen og ringte familien. De hadde ikke noen anelse om hvordan de skulle få ham hjem. Da tenkte jeg at dette kan vi gjøre noe med, forteller Erlid.

Sammen med anestesioverlege Marius Filtvet tok han tak i saken. Etter flere runder med ulike flyselskaper fikk de omsider den bevisstløse mannen hjem.

Erlid anslår at han og teamet har vært på drøyt 110 oppdrag siden starten. Hovedgruppen av dem som benytter tjenesten er menn mellom 45 og 75 år, og de aller fleste har tilhold i Thailand. Ulykker, alkohol, rus, psykiatri, somatisk sykdom - gruppen er mangfoldig og behovene til den enkelte varierer sterkt.

- Jeg har fått hjem flere som virkelig har hatt behov for å komme ut av alkoholens grep. Andre har vært i ulykker eller er blitt brått og alvorlig syke. Som regel er det de pårørende som er bekymret for sine og tar kontakt.

Det er ikke alltid like lett. Noen ganger må det letes nøye for å finne den som er savnet. De er å finne på sykehus, på en bar eller på et hotell.

- I tillegg er det et $\emptyset$ kende problem at personer med begynnende demens reiser ut og blir dårlige i utlandet. En ekstra utfordring når det er en psykiatrisk komponent er at vi ikke har lov til å ta med noen som motsetter seg det, selv om de er aldri så syke. Dermed kan et oppdrag kreve mye tid og ressurser, sier han.

Nøkkelordet for Erlids virke er reiseforsikring. Hvor og hvor lenge gjelder den? Og ikke minst - når er det den ikke gjelder? Ifølge en av Norges største forsikringstilbydere gjøres hele $20 \%$ av nordmenns utenlandsreiser uten reiseforsikring. For noen er det et bevisst valg, for andre handler det om en misforståelse i et intrikat sett av vilkår og begrensninger.

- I tillegg kommer rus, som er et stort problem selv om du har reiseforsikring. Blir du psykisk eller fysisk syk eller skadet i utlandet under samtidig påvirkning av rusmidler, kan 
du havne i en knipe. For dem som er under psykiatrien, kan det bety tap av Helsedirektoratets hjemtransport på statens regning. Hvis du har kommet ut for en ulykke og det påvises bruk av rusmidler, sier også reiseforsikringen takk og farvel i de fleste tilfeller, sier Erlid.

- Det skal også vites at ikke alle sykehus i utlandet er like tilbakeholdne som vi er her hjemme med å gi ut informasjon til forsikringsleverandøren.

Det handler ikke bare om å hente pasienten hjem på en-to-tre. Først må det økonomiske på plass. Deretter må de få tak i pasientens medisinske bakgrunnshistorie, enten fra Norge eller fra sykehuset der vedkommende er innlagt. Til sist må pasienten være i stand til å tåle transporten. Kreves det båre, må man søke om dette.

- Det kan være at familien ikke har klart å rydde opp i de økonomiske forpliktelsene overfor sykehuset, og enkelte ganger prøver vi aktivt å prute ned eller få rabatt på for store sykehusregninger. Planlegging er noe vi ikke kommer utenom, sier Erlid.

- Summen av dette gjør at vi er avhengige av fleksible og dyre flybilletter. Pasienten må fraktes i henhold til sin tilstand, og vi må ha rom til å gi den medisinske støtten som trengs. Det koster penger. Men til sammenligning vil en hjemreise på båre med ambulansefly komme opp i millioner på sluttregningen.

\section{Faktura til besvær}

Mangfoldet av tilfeller er en faglig utfordring for selskapet og setter virksomheten på prøve. De møter gjerne familier og enkeltmennesker som brått og uforutsett må håndtere store $\emptyset$ konomiske utgifter på toppen av alvorlig sykdom.

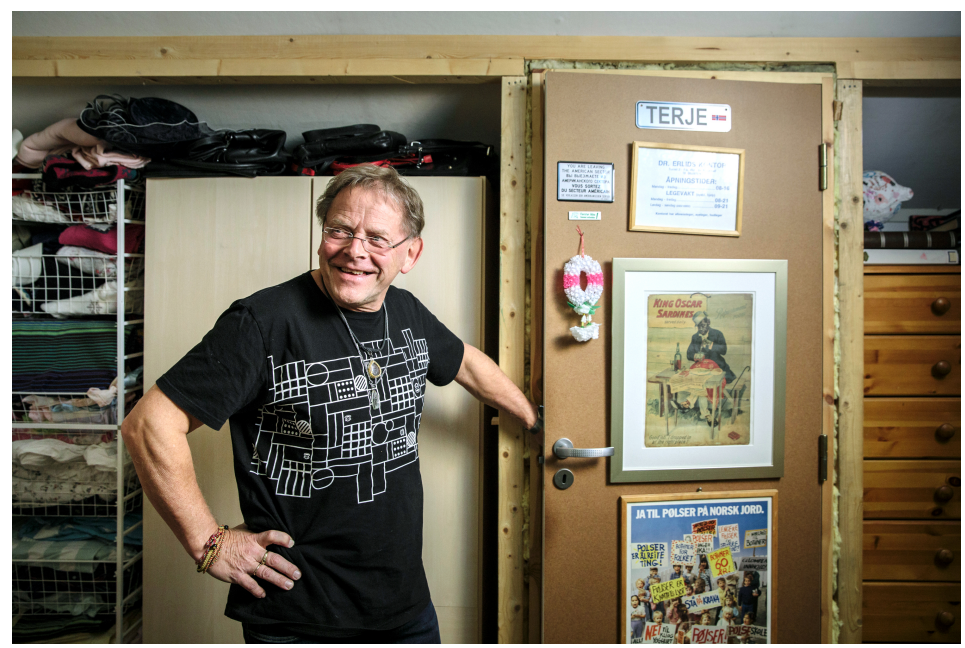

- Under slike omstendigheter skal dere drive virksomhet. Hvordan reagerer folk på sluttfakturaen?

- Altså, de er glade for å få sine hjem. De ser at dette koster veldig mye. Vi er ikke et overpriset selskap på noen måte.

- Men dere driver heller ikke veldedighet?

- Nei. Det har vi ikke råd til. Men jeg tør påstå at vi er rimelige. Dette kan ikke overprises. Folk har ikke så mye penger. De fleste har reist ut i god tro. Enten har de glemt forsikringen eller så var ikke dekningen så god som de trodde, sier Erlid.

I 2016 var han 19 ganger i Thailand, seks ganger på Filippinene, én gang i Nicaragua og tre ganger i Europa.

- I oktober 2017 var det en sak i Dagbladet med tittelen Kjendislege krevde businessbilletter og kjempehonorar for å få dødssyke Harry (66) hjem fra Kina. Den tittelen er ganske voldsom?

- Dette var en veldig spesiell sak. Én versjon av en historie er blitt presentert rått, mens kommentaren jeg skrev til Dagbladet om dette ble klippet fullstendig ned med hagesaks. Jeg sa veldig mye mer enn det som ble presentert, sier han. 
I dette tilfellet valgte pasienten ifølge Terje Erlid og Dagbladets artikkel å reise hjem fra Kina selv, etter at han og pårørende hadde vært i kontakt med Erlid.

Ifølge ham hadde Medicteam allerede reservert billetter og satt i gang prosessen med å skaffe visum da pasienten fant en annen løsning. Erlid sendte faktura, familien gikk til Dagbladet - og ingen har betalt regningen.

- Noe av det familien kritiserer deg for, er en «innsamlingsaksjon» startet på din egen Facebook-side for å bidra til pasientens hjemreise. Hva skjedde der?

- Jeg glemte å avslutte den med det samme, siden jeg var på et annet oppdrag. Dermed kom det inn 5000 kroner, som giverne ga tillatelse til skulle brukes på neste transport.

Dagbladet fremstiller historien ved å smøre sammen en hel del ting jeg ikke kjenner meg igjen i, for å si det rett ut. Jeg føler selv at jeg har mitt på det rene, sier han.

Erlid har kontaktet PFU om avisartikkelen som skapte blest i oktober. Han planlegger å følge opp med en klage i begynnelsen av 2018.

\section{På kontoret}

Vi går opp i husets andre etasje, til hunden Mikos gjøende protest. Fugemassen tyter ut på hver side av bærebjelkene rundt døren som leder inn til Erlids eget lille krypinn. Man bruker ikke tid på listverk når livsverket har retning ut og vekk og tilbake igjen. Noen ganger er det viktigere hva som fyller veggene og hva huset rommer enn at kantene er vinkelrette.

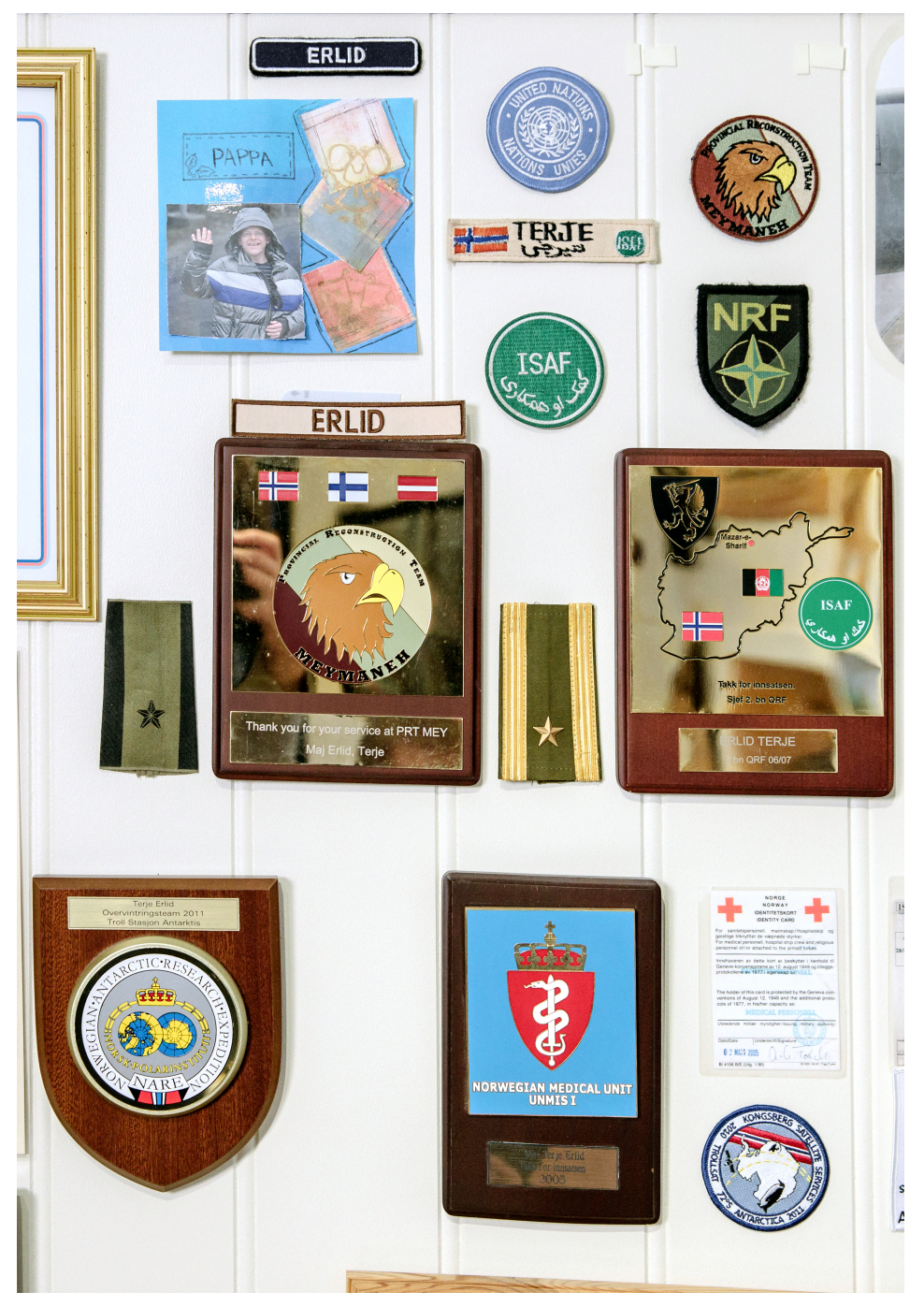

- Ja, her har jeg litt av hvert, sier Erlid, og peker på det ene minnet etter det andre.

En livbøye fra Stockholm har klemt seg plass oppe over det ene skapet, et bilde fra barndommen henger kloss opptil ulike sertifikater og attester i glass og ramme. 
Et navneskilt henger på selve inngangsdøren - et lite, men viktig klenodium. Dette fikk han utlevert da han i 2010-11 overvintret på forskningsstasjonen Troll i Antarktis. I 13 måneder var han på post som stasjonens eneste lege.

- Hadde jeg hatt muligheten, ville jeg gjerne gjort det igjen. Men av hensyn til familien og meg selv vet jeg at det ikke kommer til å skje, sier han om tiden i isødet.

- Det var en lærerik opplevelse. I løpet av de antarktiske sommermånedene var anlegget fullt av ulike forskningsgrupper. Men i de mørkeste vintermånedene var det kun seks på stasjonen. Slikt blir det tette bånd av, sier han.

Frem til 2005 hadde allmenn- og sjømannslege Terje Erlid egen klinikk i hjembyen Harstad. Den hadde han holdt gående i drøyt 25 år, men så ble han lut lei, som han sier selv. Den tidligere militærnekteren solgte klinikken og tok seg jobb i Forsvaret. I løpet av en treårsperiode var han på flere ulike oppdrag, både i Sudan og i Afghanistan.

«Den brede erfaringen og den fysiske formen var det som gjorde at han egnet seg som min etterfølger», forteller Marius Filtvedt, legen som i 2010 valgte Erlid til sin etterfølger på Troll. «Men at han kunne løpe trekilometeren på 29 minutter i 12 prosent motbakke måtte han etter hvert innrømme var noen år tilbake», forteller Filtvedt.

Vi løper ingen trekilometer i dag, vi beveger oss varsomt rundt på hålkeføret i Harstad by, på jakt etter oversikt - et bilde som kan sette Erlid i sammenheng.

Byen er bygd opp etter flere åssider, på den siden av åsen som vender mot dagsolen. På Harstadåsen var det ikke lett å finne et utkikkspunkt, men på Samaåsen, der TV-tårnet står, er det laget en skikkelig stor gapahuk for folk som vil ta byen i øyesyn fra toppen. På den siste veistrekningen mot det øverste utkikkspunktet ga vi tapt og svingte av der bebyggelsen ender. Med glatthålke på veien og en særdeles reiseforsikringsbevisst passasjer i bilen var det tryggere å finne en annen «location».

I løpet av året har Erlid mange reisedøgn i embets medfør. Men når han er tilbake i Harstad, er det gjerne på Sjøkanten senter han finner seg en kaffekopp og treffer gode venner. Vi svinger innom. Her er de store butikkjedene og den knasende lyden av gamle kaller som trasker med brodder over flisgulvet i formiddagsrushet.

Hei! Heihei, heia. God dag! Nikk. Smil og hilsener til høyre og venstre.

På vår ferd inn dørene på senteret, og mens vi passivt står opp rulletrappen og passivt står ned rulletrappen igjen, har Erlids nakke nikket til høyre og venstre.

- Det er ikke langt mellom kjentfolkene, sier han.

\section{Vi trenger ærligere forsikringer}

Et stort antall nordmenn velger hvert år å ta lengre opphold på fjerne strender under tempererte parasollskygger, langt unna de mørkeste vintermånedene. Noen tilbringer mer av livet borte enn hjemme. Målgruppen for Medicteam er stor og godt voksen, om enn ikke alltid frisk og rask. 


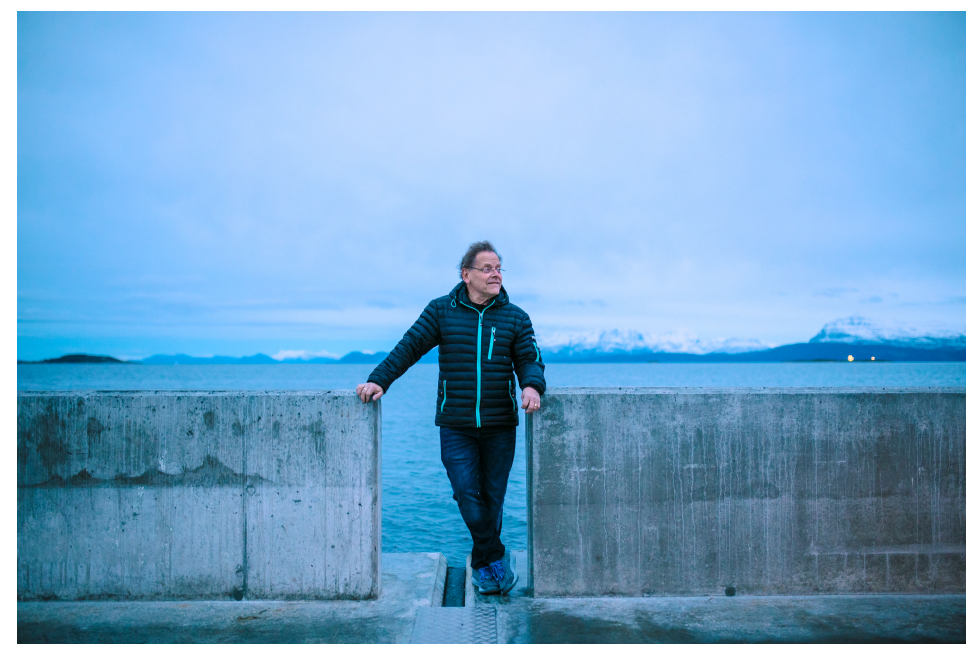

Erlid holder fast på to kjepphester, på vegne av sin pasientgruppe: - Forsikringsselskapene må omformulere det de selger inn som en «helårsforsikring». Etter min mening blir forbrukeren lurt trill rundt - det har jeg også formidlet til selskapene flere ganger, sier han.

- Det andre viktige poenget er hvordan vi forholder oss til psykisk helse og pass. Mange psykisk syke burde få passet suspendert av politiet etter råd fra psykiateren. Dette er det hjemmel for i passloven. Det er ikke de pårørende som skal ta vare på passet til den syke, det fører bare til press mot dem for å få passet ut. Det har vært episoder der den syke gir opp å mase, melder passet tapt og får utstedt et nytt uten problemer. Dette har skapt unødig mange farlige situasjoner, der de pårørende sitter igjen med en stor belastning, sier Erlid.

Vår rundtur i byen endte til sist opp på Harstads nyeste havneattraksjon: En lang og besøksvennlig flytebrygge i betong. Den har overlevd de første høststormene og vil kanskje holde vinteren igjennom. Herfra glitrer byen ved havet stille under en mørk himmel mellom milde fjell.

I 2018 fyller Erlid 7o år, men han har ikke selv planer om noen feiring. Ikke mer enn å nyte hver dag med god helse og all den tiden han har mulighet til å gjøre det han liker.

- I februar 2013 ble jeg operert for kreft. Inngrepet ble gjort i Oslo av en kullkamerat, og han gjorde en god jobb. Pseudomyxoma peritonei. De tok ut milt og galleblære, og jeg fikk anlagt stomi. Jeg var tre uker på sykehuset der før jeg kom hjem i rullestol. Jeg klarte ikke å gå og holdt stort sett sofaen her i to-tre uker, forteller han.

Han var vant til en aktiv og selvstendig tilværelse, og det var krevende å komme seg etter operasjonen. Det ble en uventet tilleggsbelastning å akseptere at livet heretter ble med stomi.

- Det som ble redningen der og da, var at noen andre trengte hjelp, forteller han.

Telefonen ringte fra Thailand. Noen trengte bistand til å komme seg hjem, og Erlid forteller at han bestemte seg for å ta oppdraget. Dermed klarte han å komme seg på bena igjen.

Gitt hans daværende tilstand og dagens tema blir neste spørsmål nesten litt for opplagt.

- Hadde du reiseforsikring?

- He-he, ja. Reiseforsikringen, den har jeg orden på.

Publisert: 5. februar 2018. Tidsskr Nor Legeforen. DOI: 10.4045/tidsskr.17.1074

(C) Tidsskrift for Den norske legeforening 2020. Lastet ned fra tidsskriftet.no 